\title{
PELATIHAN VALUE CHAIN STRATEGY UNTUK MEMPERTAHANKAN KUALITAS LAYANAN SELURUH STAKEHOLDER RUMAH SAKIT ST. ELIZABETH SEMARANG
}

\author{
Ignatius Roni Setyawan ${ }^{1}$ \\ ${ }^{11}$ Jurusan Manajemen, Universitas Tarumanagara \\ Email:ign.s@fe.untar.ac.id
}

\begin{abstract}
ABSTRAK
Rumah sakit (RS) di Amerika Serikat telah mengenal Value Chain Strategy dari Swayne, et al (2006) yang terbukti membawa dampak positif bagi pemertahanan kualitas layanan seluruh stakeholder. Hal ini dikarenakan value chain strategy merupakan pengembangan dari Porter Vakue Chain yang diadaptasikan untuk rumah sakit. Selanjutnya berbekal pada potensi masih barunya value chain strategy untuk kasus Rumah Sakit di Indonesia dan atas undangan dari pihak RS St. Elizabeth Semarang maka pelatihan ini diadakan untuk membantu pihak manajemen lebih mengenali komponen organizational value chain semua unit kerja sehingga mampu menaikkan nilai tambah mutu layanan demi menjaga level nilai paripurna pada Akreditasi Rumah Sakit. Hasil pelatihan di Pusdiklat RS St Elizabeth 16 Mei 2018 menemukan faktor competitive advantage RS Elizabeth terletak pada After Services yakni banyaknya klaim BPJS (Badan Penyelenggara Jaminan Sosial) Kesehatan yang tertangani dengan sangat baik. Sedangkan pada tahapan stakeholder analysis \& balance scorecard strategy map ditemukan bahwa faktor pasien menjadi hal terpenting. Hal ini dikarenakan pasien memiliki relasi paling banyak dengan stakeholder yang lain; di samping dalam balance scorecard strategy map untuk rumah sakit maka pasien akan mencerminkan organizational value chain terkait. Pada pernyataan visi $\&$ misi ditemukan hampir semua komponen misi dari Fred. R. David sudah tercerminkan dengan baik dengan komponen paling tersorot adalah pasien (customer). Berdasarkan hasil temuan pelatihan di atas maka pihak manajemen RS St. Elizabeth diharapkan dapat lebih mengarahkan stakeholder analysis dan value adding strategy pada factor pasien. Dalam hal ini mereka akan mampu menyusun organizational value chain pada pengembangan bisnis \& layanan medis bermutu tinggi.
\end{abstract}

Kata kunci: organizational value chain, stakehoder analysis, value adding strategy, balance scorecard strategy map

\section{PENDAHULUAN}

Sebagai salah rumah sakit yang terbesar dan ternama di kota Semarang maka RS St. Elizabeth perlu senantiasa adaptif terhadap perubahan lingkungan dan evaluatif terhadap capaian kinerja di semua unit kegiatan yang dikelola. Masuknya rumah sakit asing ke Indonesia terutama representatif atau cabang-cabang rumah sakit dari Malaysia dan Singapura ditambah perubahan aturan pemerintah terkait profesi kedokteran (IDI), tenaga medis \& keperawatan serta tenaga penunjang membuat tim manajemen RS Elizabeth senantiasa perlu mengevaluasi visi, misi dan strategi dengan baik sehingga tekanan persaingan dari rumah sakit asing dan rumah sakit nasional milik pemerintah dan swasta dapat selalu teratasi. Demikian pula dengan sikap kritis pada capaian kinerja unit maka tim manajemen RS Elizabeth dapat memenuhi tuntutan komponen internal inti yakni dokter, tenaga medis \& keperawatan. 
Adapun beberapa unit kegiatan yang dikelola RS Elizabeth Semarang antara lain: unit penerimaan pasien rawat jalan, unit penerimaan pasien rawat inap, unit ambulans, unit instalasi gawat darurat, home care, customer services rawat jalan, customer services rawat inap; marketing dan sekretariat. Menurut pemahaman kami maka unit kegiatan inti RS Elizabeth seperti lazimnya rumah sakit adalah unit penerimaan pasien rawat jalan, unit penerimaan pasien rawat inap, unit ambulans, unit instalasi gawat darurat dan home care. Sementara unit kegiatan penunjang adalah customer services rawat jalan, customer services rawat inap; marketing dan sekretariat. Secara konsep manajemen strategik yakni value chain dari Michael Porter maka tim manajemen harus mampu mensinergikan unit inti dan unit penunjang guna mencapai tujuan dan sasaran yang sudah dibuat. Sinergi yang diharapkan adalah hubungan kerja yang harmonis setiap dokter dengan tenaga medis dan keperawatan dan mampu bekerjasamanya unit inti \& penunjang untuk setiap proses kritis [sesuai studi Hidayah (2017)].

Pada tampilan website terkait kami hanya menemukan permasalahan pada deskripsi tugas setiap unit kegiatan inti dan penunjang yang belum dituliskan di website. Penulisan deskripsi tugas akan bermanfaat untuk mendukung sinergisitas antara kedua unit kegiatan dan menjamin pencapaian sasaran dan tujuan dari tim manajemen RS Elizabeth. Sehubungan dengan masalah intensitas persaingan dengan RS Asing dan sinergisitas unit kegiatan inti \& penunjang RS Elizabeth maka kami mengusulkan rumusan value chain dari Michael Porter yang sudah banyak dipakai organisasi bisnis di dunia termasuk rumah sakit [lihat Porter \& Teisberg (2004)]. Rumusan value chain tersebut akan lebih merealisasi deskripsi tugas, aliran informasi dan komunkasi antar komponen organisasi dalam RS Elizabeth meliputi dokter, tenaga medis dan keperawatan serta tenaga lainnya. Sementara untuk masalah tercakupnya komponen misi Fred R. David, maka kami mengusulkan dilakukan evaluasi dan sosialisasi visi \& misi yang melibatkan seluruh komponen organisasi. Seperti halnya organisasi yang ada di setiap industri maka RS Elizabeth perlu menjaga kesinambungan akreditasi Kemenkes \& IDI (Ikatan Dokter Indonesia).

Di kota Semarang sepengetahuan kami sudah ada RS Asing yakni RS Columbia Asia yang berlokasi dekat Bandara Ahmad Yani, di Kalibanteng. Memang benar bahwa RS Columbia Asia ini belum terlalu mengancam langsung eksistensi kegiatan RS di Semarang, namun ada poin laten yang perlu diwaspadai yakni potensi berpindahnya calon pasien terutama pasien rawat inap ke RS Asing. Hal ini perlu disadari oleh tim manajamen RS Elizabeth bahwa RS Columbia Asia seperti halnya RS Asing dari Malaysia dan Singapura sudah menerapkan konsep value chain strategy yang belum begitu populer untuk rumah sakit di Indonesia. Inti value chain strategy menurut Swayne, et al (2006) adalah harmonisasi semua faktor competitve advantage Services Delivery \& Supporting Activities dengan analisis Stakeholder sehingga melahirkan balance scorecard strategy map yang memuat desain organizational value chain yang tepat.

Dua hasil studi empirik sebelumnya mencatat pentingnya pendesainan organizational value chain bagi rumah sakit. Pentingnya pendesainan organizational value chain ini adalah pada penciptaan keunggulan kompetitif (nilai tambah) bagi organisasi. Seperti pada studi Handayani, et.al. (2016) pada kasus rumah sakit Islam Kendal menemukan diferensisasi bentuk layanan pada pasien geriatri (usia lanjut) akan menciptakan keunggulan kompetitif bagi rumah sakit terkait karena bisa jadi rumah sakit yang lain akan lebih fokus pada pasien usia produktif (non geriatri). Dan yang lain lagi studi Nugroho (2013) untuk kasus Rumah Sakit Islam NU, Demak yang menemukan ada empat bentuk keunggulan kompetitif pada unit layanan Trauma Center yakni letak geografis, pengembangan layanan TC, tenaga medis profesional dan layanan-layanan pendukung. Berdasarkan temuan dua studi ini, maka kegiatan pelatihan ini akan difokuskan pada pembahasan organizational value chain meliputi Analisis Lingkungan Internal dan Keunggulan Kompetitif, Analisis Lingkungan Eksternal \& Value Adding Strategy RS ini. 
Dengan begitu pelatihan ini bertujuan pertama, mengenalkan dan membahas komponen organizational value chain dari Swayne, et.al. (2006) yakni Services Delivery \& Supporting Activities. Service Delivery merupakan bagian inti dari organizational value chain yang berfokus pada pre servives, point of services dan after services pada pasien dan keluarganya. Services Delivery akan maksimum jika disinergikan dengan support activities. Motivasi tujuan pertama adalah membuktikan anggapan sebagian nasyarakat di Semarang bahwa kekuatan RS Elizabeth ada pada after services yakni klaim BPJS yang tertangani dengan baik.

Tujuan kedua yakni mengenalkan dan membahas penerapan organizational value chain dalam value adding strategy meliputi tahapan stakeholder analysis \& balance scorecard strategy map. Stakeholder analysis adalah pemetaan seluruh komponen stakeholder rumah sakit yang meliputi regulator, relasi pasien, perusahaan farmasi, asuransi kesehatan dan praktik medis kelompok multispesialis. Sedangkan balance scorecard strategy map adalah membawa hasil desain organizational value chain yang disusun untuk dibahas efektivitasnya pada tujuan utama dari organisasi rumah sakit yakni pada pengembangan bisnis \& layanan medis bermutu tinggi. Motivasi tujuan kedua adalah ingin membuktikan apakah faktor relasi pasien memang yang paling dominan merujuk pada hasil studi Swayne, et.al. (2006) di Amerika Serikat. Untuk memperkuat stakeholder analysis \& balance scorecard strategy map juga dilakukan bedah visi misi dari RS Elizabeth dengan mengambil pernyataan visi dan misi yang ada di website www.rs-elizabeth.com.

\section{METODE PELAKSANAAN PKM}

\section{a. Persiapan Pelaksanaan PKM}

Berdasarkan hasil diskusi kami sebelumnya pada tanggal 18 Maret 2018 dengan Sr. Victorine Ida Nursanti, OSF, BSN, MHA (Direktur Ekseskutif RS Elizabeth) maka telah disepakati bahwa tema kegiatan adalah workshop penerapan strategi mempertahankan mutu pelanggan dalam rangka menjamin efektivitas dari implementasi visi \& misi RS Elizabeth.

Selanjutnya berdasarkan survai literatur yang dilakukan dari 19 Maret s/d 1 April 2018 maka kami menemukan literatur manajemen strategik khusus untuk institusi kesehatan seperti rumah sakit. Dalam literatur manajemen strategik yang ditulis Swayne, et..al (2006), maka kami menemukan satu bab yang cocok dengan tema kegiatan yakni Internal Environmental Analysis \& Competitive Advantage oleh karena di dalam bab tersebut ada strategic tool bernama Organizational Value Chain hasil karya Michael Porter yang sudah banyak dipakai \& diakui karena efektivitasnya pada berbagai industri (detilnya pada hasil \& pembahasan).

Dalam database Komite Akreditasi Rumah Sakit (detilnya pada hasil \& pembahasan) maka ditemukan bahwa RS Elizabeth masih berada dalam level paripurna dengan perbandingan dua Rumah Sakit besar di Semarang yakni RS Kariadi dan RS Telogorejo. Memang sudah selayaknya jika RS Elizabeth masih berada dalam level paripurna dan jika perlu naik level kelas menjadi A seperti RS Kariadi mengingat kedua RS ini sama-sama tertua di Semarang.

\section{b. Pelaksanaan PKM}

Kegiatan pelaksanaan yakni Rabu, 16 Mei 2018 jam 8-12 WIB ini dibuka oleh dr. P. Nani Wijaya, Sp. P.A selaku kepala Pusdiklat RS St. Elizabeth, Semarang yang menyatakan relevansi topik pelatihan dengan situasi persaingan rumah sakit sekarang ini yang benar-benar berorientasi pada pelanggan (pasien \& keluarganya). Relevansinya adalah jika para peserta pelatihan yang terdiri dari perwakilan manajemen, perwakilan dokter, tenaga medis \& keperawatan, pewakilan unit penerimaan pasien (rawat jalan \& rawat inap), perwakilan unit customer services (rawat jalan $\&$ rawat inap), perwakilan unit ambulans, instalasi gawat darurat 
serta perwakilan unit marketing dan sekretariat memahami dan mengenali komponen organizational value chain maka semua unit kerja di RS Elizabeth akan mampu menaikkan nilai tambah mutu layanan sehingga dapat meningkatkan level nilai paripurna Akreditasi RS dari B menjadi A serta dengan mengenali stakeholder analysis dan value adding strategy maka pihak manajamen dapat menentukan faktor competitive advantage untuk pengembangan bisnis \& layanan medis bermutu tinggi.

Sesi pelatihan meliputi beberapa bagian penting menurut SNARS (2018) meliputi: a) Profil singkat RS Elizabeth meliputi sejarah singkat, database KARS (Komite Akreditasi Rumah Sakit) dan data RS lain di Semarang sebagai benchmark. b) Analisis Lingkungan Internal dan Keunggulan Kompetitif RS dengan memakai referensi Swayne, et.al. (2006), Strategic Management of Health Care Organization c) Analisis Lingkungan Eksternal \& Value Adding Strategy d) Pembahasan singkat visi \& misi RS dengan merujuk Fred. R. David.

Pada pembahasan analisis internal ini maka dijelaskan dengan detil tentang model organization value chain dari Porter yakni services delivery activities terdiri dari pre services, point of services dan after services. Kemudian juga berikutnya adalah komponen supporting activities yakni organizational culture, organizational structure dan strategic resources. Pada masing-masing bagian dijelaskan secara terperinci dan dibahas juga kekuatan dan kelemahan masing-masing untuk dirumuskan value adding strategy terkait guna merealisasi pencapaian mutu organisasi suatu RS.Berikutnya adalah pembahasan analisis eksternal yakni a) Komponen vital stakeholder Rumah Sakit yang akan meliputi: patient, hospital \& physicians. b) Partnership Model Scorecard yang mengintegrasikan organizational value chain dari RS berpusat pada patient dengan 3 perspektif lain dalam BSC (Balance Score Card) yakni financial, internal dan learning \& growth.
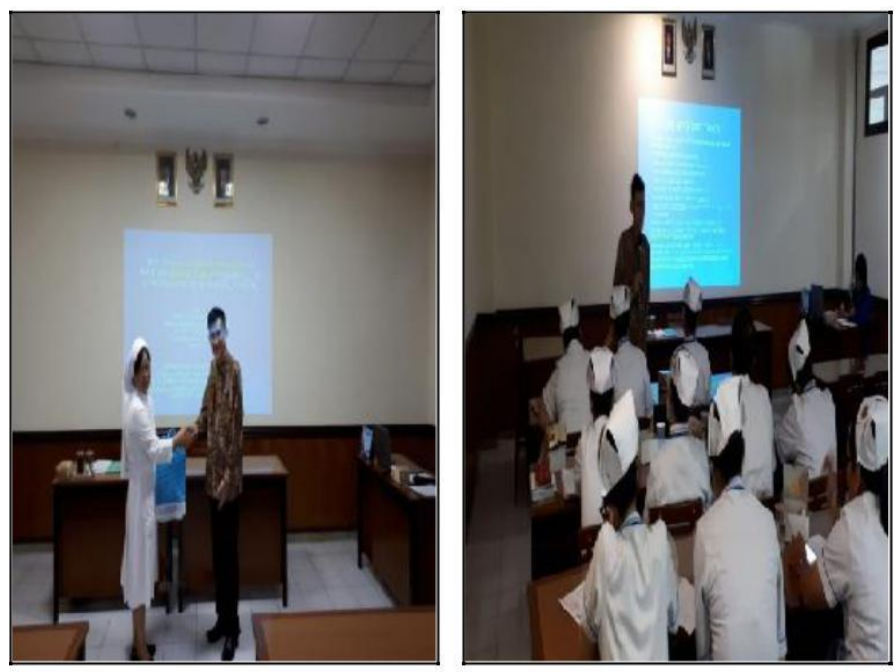

Penyerahan kenangankenangan dari perwakilan manajemen RS St Elizabeth (seorang Suster Biarawati)

Saat kami membawakan materi pelatihan topik Applying Vakue Chain Stategy terkait

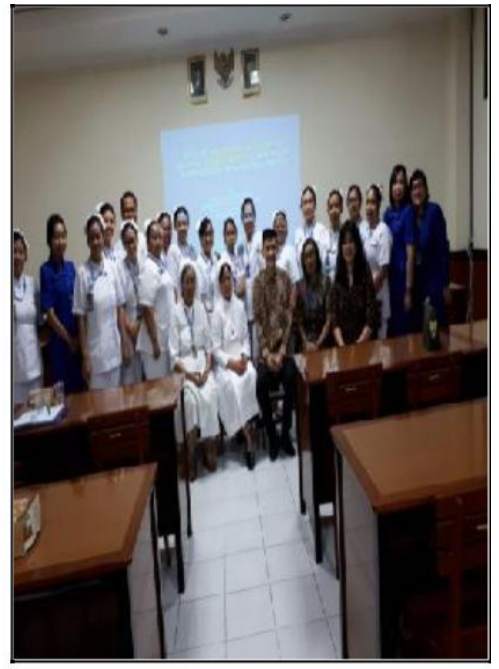

Foto besama dengan para peseta pelatihan, kami (duduk) diapit oleh 2 Suster Biarawati \& dr. P. Nani Wjaya (paling kanan) 
Kegiatan ini kemudian kami akhiri dengan beberapa poin penting bahasan yakni: 1) Untuk mencapai level tertinggi pelayanan, maka RS senantiasa merumuskan competitive advantage, selalu memperbaharui organizational value chain beserta seluruh komponennya, melakukan analisis kekuatan dan kelemahan secara periodik services delivery activities dan supporting activities guna menentukan value adding strategy yang relevan, memahami pengertian mendalam dari kapabilitas, kompetensi dan sumberdaya sebagai taksonomi klasifikasi value chain component. 2) Pada bagian analisis eksternal perlu analisis rinci stakeholder RS dan pengintegrasian komponen organizational value chain dengan tiga pilar BSC yang lainnya guna membentuk Partnership Model Scorecard yang solid. 3) Dalam hal evaluasi visi \& misi RS Elizabeth maka sudah dapat dinilai baik. Hal ini dibuktikan dari sikap dan jawaban positif peserta sebelum, selama dan setelah acara pelatihan ini dan berbagai testimonial tokoh ternama yang ada di website RS Elizabeth misalnya bapak Irwan Hidayat (CEO PT Sido Muncul).

\section{HASIL \& PEMBAHASAN}

a) Profil Singkat RS Elizabeth

RS Elizabeth didirikan pada tanggal 3 September 1923 dengan dimulai dari pembelian sebidang tanah seluas $34.000 \mathrm{~m} 2$ di daerah perbukitan Candi Baru. Pembangunan gedung RS selesai pada 8 Agustus 1927. Tanggal 18 Oktober 1927 RS Elizabeth resmi dibuka oleh MGR. van Velsen, SJ. RS ini tidak dapat beroperasi selama zaman pendudukan Jepang hingga serah terima kembali pada 1 September 1945. Kemudian pada 3 September 1945 resmi mulai lagi oleh karya Sr. Charitas Lammerink \& 2 suster lain hingga akhirnya RS Elizabeth terus mengalami banyak kemajuan \& memiliki beberapa cabang RS di Indonesia.

Berdasarkan tabel 1 di bawah ini maka dapat diperbandingkan antara profil RS Elizabeth Semarang dengan RS Kariadi dan RS Telogorejo. Ketiga RS merupakan RS yang memiliki brand image yang bagus di kota Semarang. Brand Image ini tercipta dari empat komponen penting yakni identitas rumah sakit, akreditasi rumah sakit, dokter (umum \& spesialis) dan fasilitas-fasilitas kesehatan lainnya. Empat komponen ini pada dasarnya mencerminkan dimensi kualitas dari sebuah rumah sakit. Data-data profil ini dipublikasi oleh Komite Akreditasi RS.

Tabel 1. Profil Data Rumah Sakit Elizabeth Semarang \& Dua RS Pembanding

\begin{tabular}{lccc}
\hline \multicolumn{1}{c}{ Komponen Data } & RS Elizabeth & RS Telogorejo & RS Kariadi \\
\hline Kode RS & 33704021 & 3374043 & 3374010 \\
\hline Tanggal Registrasi & $23 / 12 / 2009$ & $12 / 01 / 2013$ & $31 / 10 / 2013$ \\
\hline Jenis & RSU & RSU & RSU \\
\hline Kelas RS & B & B & A \\
\hline Status Akreditasi & Tingkat & Tingkat & Tingkat \\
& Paripurna & Paripurna & Paripurna \\
\hline Tanggal Akreditasi & $18 / 04 / 2017$ & $23 / 07 / 2013$ & $28 / 02 / 2015$ \\
\hline Jumlah Dokter Umum & 40 orang & 29 orang & 22 orang \\
\hline Kisaran Jumlah Dokter & $90-100$ orang & $115-125$ orang & $110-120$ orang \\
Spesialis & & & \\
\hline
\end{tabular}

Sumber: Database Komite Akreditasi Rumah Sakit (2018) 


\section{b) Analisis Lingkungan Internal dan Keunggulan Kompetitif RS berrdasar studi Swayne, et.al. (2006), Strategic Management of Health Care Organization.}

Analisis ini akan mengidentifikasi komponen detil service delivery dan support activities (terlampir di gambar 1). Keunggulan kompetitif dari RS Elizabeth terletak pada komponen after services yakni banyaknya klaim BPJS Kesehatan dari pasien yang terselesaikan dengan sangat baik. Hal ini memperkuat pencapaian add value melalui strong organizational culture. Artinya RS Elizabeth menetapkan pasien sebagai elemen terpenting services quality. Di samping penyelesaian klaim BPJS Kesehatan yang baik (sudah terbukti secara testimonial), RS Elizabeth juga memiliki keunggulan point of services yakni jaminan kualitas kegiatan klinis dan kepuasan keluarga pasien.

Gambar 1. Organizational Value Chain untuk RS Elizabeth

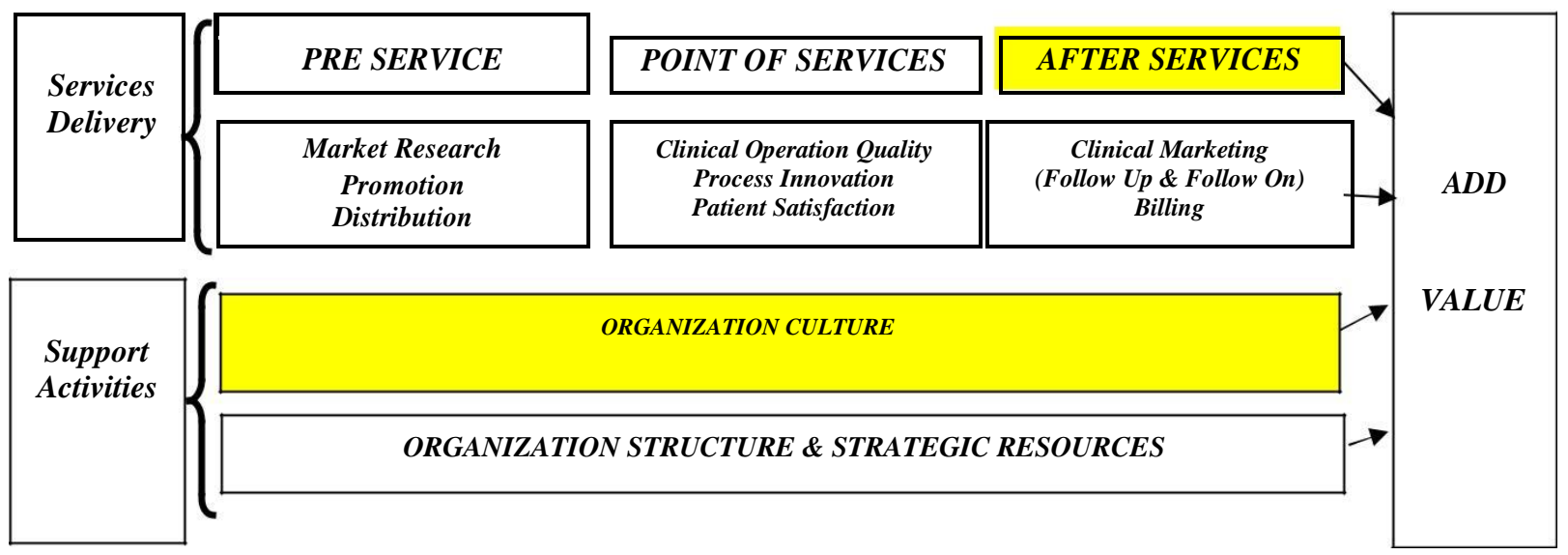

Sumber: Adaptasi Swayne, et.al. (2006), Strategic Management of Health Care Organization.

\section{c) Analisis Lingkungan Eksternal \& Value Adding Strategy}

Analisis pada gambar 2 dilakukan untuk memetakan para stakeholder dari RS Elizabeth. Berdasarkan studi Swayne, et al. (2006) maka kami mengidentifikasi ada 5 stakeholder yakni regulator, relasi pasien, perusahaan farmasi, asuransi kesehatan dan praktik medis kelompok multispesialis. Hasil diskusi selama pelatihan menemukan maka stakeholder terpenting adalah relasi pasien. Hal ini beralasan karena relasi pasien berkaitan dengan kelancaran kegiatan pelayanan medis yang melibatkan peranan langsung dari regulator dan perusahaan farmasi serta peranan tidak langsung dari asuransi kesehatan dan praktik medis kelompok multispesialis.

Gambar 2. Analisis Stakeholder untuk RS Elizabeth

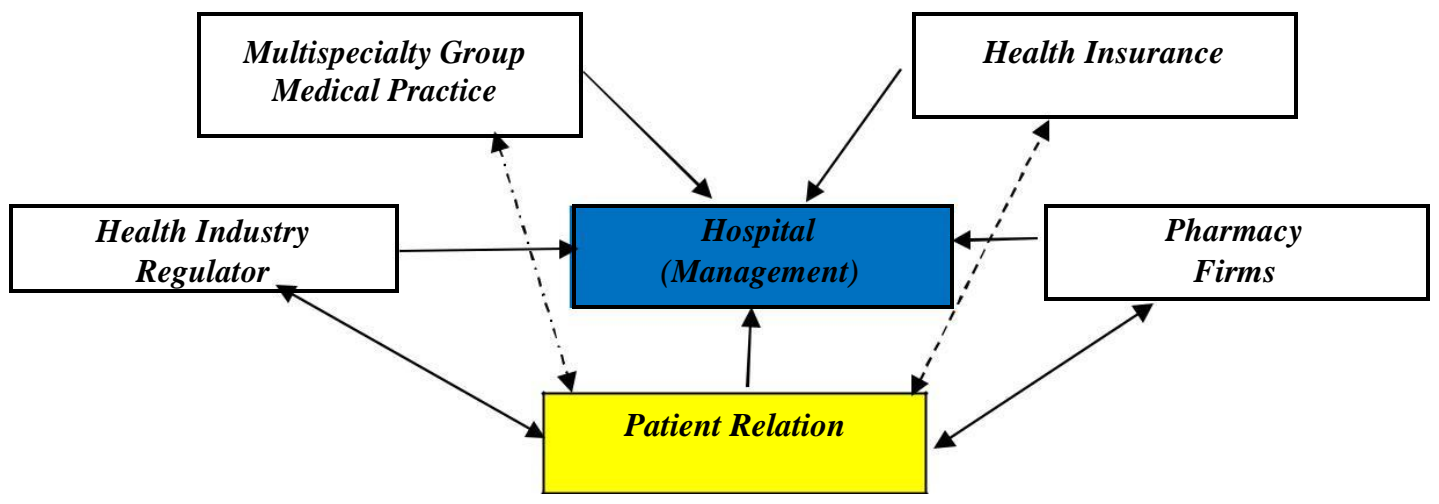

Sumber: Adaptasi Swayne, et.al. (2006), Strategic Management of Health Care Organization. 
Kegunaan analisis stakeholder di atas untuk menentukan profil value adding strategy yang diimplementasikan melalui balance scorecard strategy map di bawah ini. Pasien (Patient) menjadi perspektif terpenting balance scorecard karena merupakan representasi organizational value chain. Services delivery berhubungan dengan proses inti patient yakni clinical operation; sedang supporting activities menyangkut proses tambahan patient yaitu non clinical treatments.

Gambar 3. Balance Scorecard Strategy Map untuk RS Elizabeth

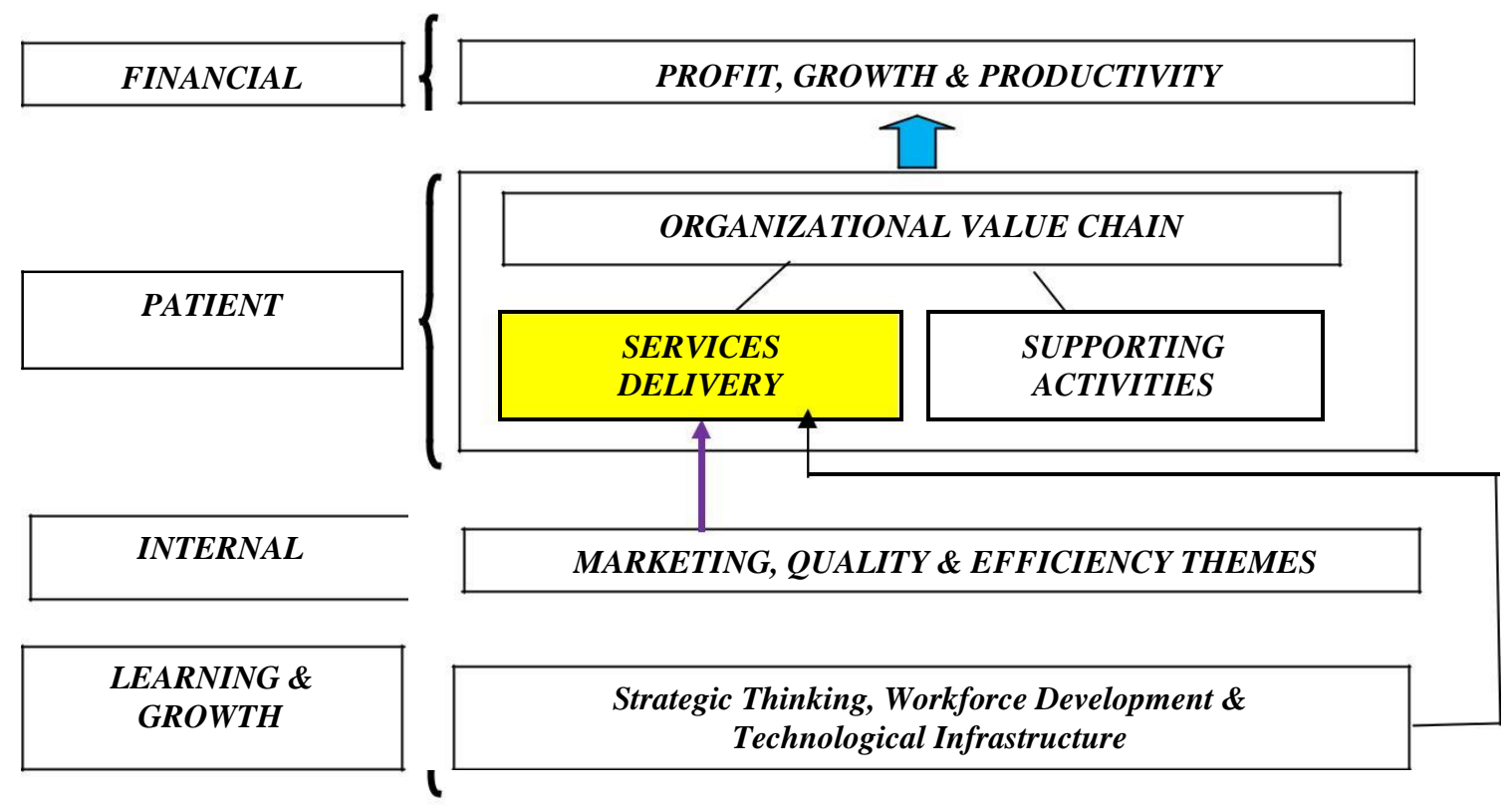

Sumber: Adaptasi Swayne, et.al. (2006), Strategic Management of Health Care Organization.

Berdasarkan gambar 3 balance scorecard strategy map, maka RS Elizabeth harus mampu mengidentifikasi kekuatan dan kelemahan dalam organizational value chain. Pasien sebagai figur sentral dalam model bisnis rumah sakit harus mendapatkan pelayanan medis terbaik \& bermutu tinggi dari dokter, tenaga medis dan keperawatan yang profesional. Makin kritisnya pasien pada pre services, point services dan after services harus diakomodasi dengan makin tingginya kompetensi dokter dan makin canggihnya fasilitas yang dimiliki. Hal ini mendukung hasil penelitian Wibisono \& Hamsal (2013) untuk RS Bhakti Timah di Pangkal Pinang, Bangka.

\section{d) Pembahasan Singkat Visi \& Misi RS Elizabeth}

Berdasarkan observasi terhadap website RS Elizabeth (www.rs-elizabeth.com.) maka kami menemukan beberapa poin penting yakni rumusan visi, misi \& motto serta beberapa unit kegiatan yang dikelola. Rumusan visi, misi \& motto RS Elizabeth Semarang sebagai berikut:

\section{VISI}

"MENJADI RUMAH SAKIT YANG MENGUTAMAKAN KESELAMATAN DAN TERPERCAYA SERTA MENJADI SARANA KEHADIRAN CINTA DAN KUASA ALLAH" 


\title{
MISI
}

\section{MENYEDIAKAN LAYANAN KESEHATAN YANG BERMUTU DAN PROFESIONAL KEPADA MASYARAKAT, TERMASUK KLMTD (KAUM LEMAH, MISKIN, TERSINGKIR \& DIFABEL) \\ 2. MEMBERI PELAYANAN YANG BERPUSAT PADA PASIEN SEBAGAI "TAMU ILLAHI"}

3. MEMBANGUN PERSAUDARAAN SEJATI DI ANTARA PELAYAN KESEHATAN, PASIEN DAN MASYARAKAT, TANPA MEMBEDAKAN STATUS SOSIAL, GOLONGAN DAN AGAMA

4. MELESTARIKAN RUMAH SAKIT SEBAGAI "HERITAGE DAN GREEN HOSPITAL"

\author{
MOTO \\ "PANCARAN CINTANYA MENYEMBUHKAN DERITA SESAMA"
}

Selanjutnya kami menemukan rumusan visi, misi dan motto yang demikian baik karena sudah memenuhi salah satu ciri khas kalimat visi \& misi dalam literatur manajemen strategik dari Fred R. David yakni "why we exist" atau "what we would like to be" serta kalimat misi yakni "what we would like to offer". Yang menjadi concern kami adalah seberapa jauh rumusan

misi sudah mencakup beberapa pilar penting dari komponen misi Fred R. David yaitu Customer, Product, Market; Technology; Concern for Survival, Growth \& Profitablity, Philosophy, Self Concept, Public Images dan Concern for Employees. Maka perlu dicek kelengkapan komponen dalam rumusan misi yang sudah ada sesuai David \& David (2017).

Berdasarkan analisis misi di atas, maka hampir semua komponen misi dari Fred. R. David sudah terpenuhi. Customer ada pada kata pasien (no.2), product ada pada kata "layanan kesehatan", market ada pada kata "masyarakat", technology ada pada kata "heritage \& green hospital", philosophy ada pada kata "Tamu Illahi", self concept ada pada kata "bermutu \& profesional", public image ada pada kata "tanpa membedakan status sosial, golongan dan agama dan KLMTD" serta concern for employees ada pada kata "persaudaraan sejati di antara pelayananan kesehatan, pasien dan masyarakat". Unsur growth \& profitability memang tidak perlu ditampilkan secara eksplisit. Sebab rumah sakit semestinya tidak akan $100 \%$ berorientasi laba seperti perusahaan. Meski era persaingan bisnis ternyata sudah merambah ke rumah sakit.

\section{KESIMPULAN \& SARAN}

Tujuan pelatihan ini pertama, mengenalkan dan membahas komponen organizational value chain dari Swayne, et.al. (2006) yakni Services Delivery \& Supporting Activities dan kedua, mengenalkan dan membahas penerapan organizational value chain dalam value adding strategy meliputi tahapan stakeholder analysis \& balance scorecard strategy map. Kedua tujuan ini secara umum telah tercapai dengan baik dari hasil kegiatan pelatihan.

Hasil pelatihan kami tanggal 16 Mei 2018 di Pusdiklat RS Elizabeth Semarang menemukan bahwa faktor competitive advantage RS Elizabeth terletak pada After Services yakni banyaknya klaim BPJS (Badan Penyelanggara Jaminan Sosial) Kesehatan yang tertangani dengan sangat baik. Sedangkan pada tahapan stakeholder analysis \& balance scorecard strategy map ditemukan bahwa faktor pasien menjadi hal terpenting. Hal ini dikarenakan pasien memiliki relasi paling banyak dengan stakeholder yang lain; di samping dalam balance scorecard strategy map untuk rumah sakit maka pasien akan mencerminkan organizational value chain terkait. 
Pada pernyataan visi \& misi ditemukan hampir semua komponen misi Fred. R. David sudah tercerminkan dengan baik. Komponen misi Fred. R. David paling tersorot: pasien (customer).

Atas dasar analisis profil Rumah Sakit berdasarkan data Komite Akreditasi Rumah sakit maka dapat ditemukan bahwa RS Elizabeth memiliki posisi yang tidak kalah bersaing dengan rumah sakit yang lain di Semarang. Hal ini dapat dilihat dari banyaknya jumlah dokter umum yang lebih besar dari RS Kariadi dan RS Telogorejo. Kebutuhan akan dokter umum seharusnya masih menjadi kebutuhan yang lebih urgen dibanding kebutuhan dokter spesialis. Dokter umum akan berhubungan dengan pasien berobat yang datangnya lebih banyak dan berfrekuensi tinggi dibanding pasien dokter spesialis yang umumnya datang untuk berkonsultasi (check-up).

Untuk meningkatkan kelas rumah sakit dari B menjadi A maka manajemen rumah sakit Elizabeth perlu membangun penerapan organizational value chain secara lebih terperinci lagi. Kunci kekuatan rumah sakit Elizabeth yang terletak pada after services harus dipertahankan dan diperluas dengan jaminan kualitas operasi medis untuk kasus penyakit-penyakit berat yang tidak tertangani di rumah sakit lain. Selain itu disertai pula dengan melakukan sinergi total dengan para stakeholder rumah sakit mulai dari relasi pasien hingga pada pihak-pihak lain terdekat seperti regulator, perusahaan farmasi dan asuransi kesehatan. Konsep medical tourism yang mulai banyak dipakai rumah sakit di Indonesia seperti Balimed perlu dirintis [lihat Putra 2014)]. Perintisan konsep medical tourism cukup beralasan mengingat banyaknya cabang RS Elizabeth di Indonesia. Banyaknya cabang rumah sakit yang dimiliki RS Elizabeth membuat manajemen dapat membangun kolaborasi lebih banyak lagi dengan new stakeholders di industri kesehatan.

\section{REFERENSI}

David, F.R. \& F.R. David (2017), Strategic Management: A Competitive Approach, $16^{\text {th }}$ Edition, Pearson Education Limited, New Jersey, USA.

Handayani, S.M, Sudiro \& A. Margawati (2016), “Analisis Strategi Pelayanan Geriatri Berbasis Rumah Sakit dengan Menggunakan Value Chain di Rumah Sakit Islam Kendal”, Jurnal Manajemen Kesehatan Indonesia 4 (1), 51 - 57.

Hidayah, N. (2017), Perencanaan Strategi Rumah Sakit, Monograf Program Studi Manajemen Rumah Sakit Program Pasca Sarjana Universitas Muhamadiyah Yogyakarta,.

Komite Akreditasi Rumah Sakit Nasional (KARS), dengan alamat website adalah http://akreditasi.kars.or.id/accreditation/report/report_accredited.php Daftar Rumah Sakit Terakreditasi, tanggal akses 16 Mei 2018.

Nugroho, T.W. (2013), “Analisis Lingkungan Internal dan Kompetitor Layanan Trauma Center RSI NU Demak”, Jurnal Keperawatan \& Kesehatan Masyarakat, STIKES Cendekia Utama Kudus, 1 (2), 23-34.

Porter, M.E. \& E.O. Teisberg (2004), "Redefining Competition in Health Care", Harvard Business Review, 82 (6), 65-76. 
Putera, I.P.W (2014), Potensi Pengembangan Medical Tourism Di Rumah Sakit Balimed Denpasar, Tesis Program S2 Ilmu Kesehatan Masyarakat UGM,

Situs resmi RS Elizabeth http://www.rs-elisabeth.com/ tanggal akses 16 Mei 2018.

SNARS (2018), Standar Nasional Akreditasi Rumah Sakit Edisi 1, Januari, Komite Akreditasi Rumah Sakit (KARS), Jakarta.

Swayne, L.E., W.J. Duncan \& P.M. Ginter (2006). Strategic Management of Health Care Organization, $5^{\text {th }}$ ed., Blackwell Publishing, Victoria, Australia.

Wibisono, M.S. \& M. Hamsal (2013), “Business Strategy Development \& Business Model RS Bhakti Timah (RSBT) Groups Pangkal Pinang Under Bhakti Timah Foundation (YBT) Become PT RS Bakti Timah as an Existence of Diversification Effort from PT Timah (Persero) Tbk", the International Journal of Business Administration, 2. (16), 2010-2019. 